\title{
The Study of Homegarden Agrobiodiversity, Practices of Homegardening and Its Role for In-Situ Conservation of Plant Biodiversity in Eastern Hararghe, Kombolcha Town Oromia Regional State Ethiopia
}

\author{
Arayaselassie Abebe Semu \\ School of Animal and Range Sciences, College of Agriculture and Environmental Science, Haramaya University, Dire Dawa, \\ Ethiopia \\ Email:pbbmaraya@gmail.com
}

How to cite this paper: Semu, A. A. (2018). The Study of Homegarden Agrobiodiversity, Practices of Homegardening and Its Role for In-Situ Conservation of Plant Biodiversity in Eastern Hararghe, Kombolcha Town Oromia Regional State Ethiopia. Open Journal of Forestry, 8, 229-246. https://doi.org/10.4236/ojf.2018.82016

Received: November 9, 2017

Accepted: April 22, 2018

Published: April 25, 2018

Copyright $\odot 2018$ by author and Scientific Research Publishing Inc. This work is licensed under the Creative Commons Attribution International License (CC BY 4.0).

http://creativecommons.org/licenses/by/4.0/

\begin{abstract}
Homegarden plays a vital role for the livelihood of the people living in town. Homegarden agrobiodiversity was studied to highlight homegarden frequency, types, plant species, growth form and associated indigenous knowledge. The research was conducted during January to April 2017. A total of 180 randomly selected households were included in the survey. Ethnobotanical data were collected from purposively selected 60 homegardens using observations and semi-structured interviews while markets survey was conducted through structured questionnaire for homegarden products. Data were analyzed using descriptive and inferential statistics and similarity and Shannon wiener diversity index. The results indicated that $128(71 \%)$ of the households were practicing home gardening. The homegarden plant composition gave 78 species belonging to 35 families. The representative families and number of species under each family were founded that the family Solonaceae, and Rutaceae rank top of the list ( 6 species) each followed by Fabaceae and Lamiaceae ( 5 species each) and Asteraceae, Poaceae, Rosaceae and Brassicaceae (4 species) each. Catha edulis, Lantana camara and Ruta chalepensis had the highest frequency of species followed by the families Asteraceae, Rutaceae and Poaceae. Catha edulis, Rhammus prinoides and Ruta chalepensis were among the families found in homegardens. It can be concluded that homegrdens of Kombolcha are rich in biodiversity. The present study showed the existing status of homegardens and local knowledge contribution to the farming systems in conservation of the biological diversity. In addition, plant species providing
\end{abstract}


substantial benefits and factors combined to determining homegarden diversity are documented.

\section{Keywords}

Homegardening, Local Knowledge, Plant Biodiversity, Homegarden, Conservation

\section{Introduction}

Biodiversity conservation is receiving increased attention of world scientists and leaders in recent decade because of the growing recognition of its importance and the adverse impacts of climate change particularly genetic diversity biodiversity. Biodiversity is usually explored at three levels: genetic diversity level, species diversity levels, and ecosystem diversity levels.. As a study in biodiversity, Ethnobotany is taken as key science for studying the local people on the botanical aspects of conservation and development. Ethnobotany remains the leading tool in finding how people have traditionally used plants (Balick et al. 1996). An ethinobotanical research is very crucial for the developing country like Ethiopia, where local people is highly dependent on local plant resources for the lively hood. Ethinobotanists reported that modernization of the world is dominating the life style of traditional societies, which is result in massive cultural and environmental changes. Indigenous knowledge is vital for sustainable agro biodiversity where the knowledge is lost at an incredible rate.

Traditional knowledge is the information that people in a given community have developed, based on experience and adaptation to a local culture and environment (Christian et al., 2004). Such knowledge is useful for reducing hazards and for maintaining cultural and biological diversity in a given society. The decline in the indigenous botanical knowledge transfer and skill of plant management are facing difficulties in their future. The role of home gardens as repositories of biological diversity has been acknowledged but still comprehensive, interdisciplinary investigation of their agrobiodiversity is lacking (Galluzzi et al., 2010). Home gardens are realized as an important self-sustaining agro ecosystem with the dual function of production and on farm conservation of agro biodiversity (Zemede \& Woldu 2002). The threat in genetic erosion to plant resources for which are useful for food and other agriculture benefits could be arrested by ensuring the worth and benefits of home gardens because they ensure conservation of useful plants through continuous use (Zemede, 2002).

Ethiopian home gardens are unique in each region and villages with their architecture, crop mix and dominant species found in the garden. The homegardens contain significant numbers of indigenous plant taxas and some of the plants taxas were domesticated in for the first time in Ethiopia like Coffea arabica, Ensete ventricosum, Coccinia abyssinica, Brassica carinata and other lesser 
known species. Homegardens in Ethiopia named in different local languages but, in English language as agro forestry home gardens, backyard gardens, farmyard, roof top garden, homestead farms and gardens (Zemede, 2002).

In Ethiopia, where there are a number of languages spoken and with diverse society structures, homegardens are called in Amharic as "yeguaro ersha" and in Oromifa language "eddo" means a land at a backyard of a house (Zemede, 2002). Home gardens commonly are systems that are essentially man-made and that reflect the wisdom of culture and ecological knowledge which evolved over the years (Kumar \& Nair, 2004 and Tigist et al., 2006). The highest diversity of plant species in the home gardens plays an essential socio-economic and ecological role due to the fact that it is related to the production of food and other products such as source of fire wood, fodder, medicinal plants, cash crops and ornamentals (Engels, 2002). In related to in situ conservation of agro biodiversity, (Eyzaguirre \& Watson 2002) describes that homegardens are taken as key places for conserving plant biodiversity. It is exhibited that home gardens are serving as refugees camp for a number of plants species especially for those plant species that are not widely grown in the larger agro ecosystem in addition to enormous indigenous knowledge (Eyzaguirre \& Linares 2004). The scope of the present study was limited to plant agrobiodiversity at species level describing floristic richness of home gardening system. It also describes their contributions to cultural identity and diversity natured by bio cultural knowledge, and to economy, nutrition and health at household level. The general aim of the study is to assess the home gardens of Kombolcha Woreda along with their traditional management practices and uses, to generate and make available information on their roles for in-situ conservation of plant biodiversity.

\section{Material and Methods}

\subsection{Description of the Study Area}

Kombolcha is one of eighteen Woredas in East Hararghe Zone. Kombolcha is located about $514 \mathrm{~km}$ from Addis Ababa and $14 \mathrm{~km}$ northwest of Harar town, the capital of the Harare people Regional state. The altitude of the Woreda ranges between 1600 - $2400 \mathrm{~m}$ asl. The Woreda is strategically located between the two main cities of Harar and Dire Dewa.

Kombolcha is bordered by the Dire Dawa City Administration to the north, Harari Regional State to the south, Jarso Woreda to the east, and Haramaya Woreda to the west. The Woreda has a rugged topography with many valleys. The northern part of the Woreda is mountainous with steep slopes. These natural features limit accessibility to some of the kebeles. Typically, the Woreda lies in lowland and midland areas. Rainfall is mainly bi-modal, but it can be erratic as well as the main rainy season is from February to mid-May and from July to end of August. Annually, the Woreda receives a mean rainfall of $600-900 \mathrm{~mm}$ (Figure 1). 


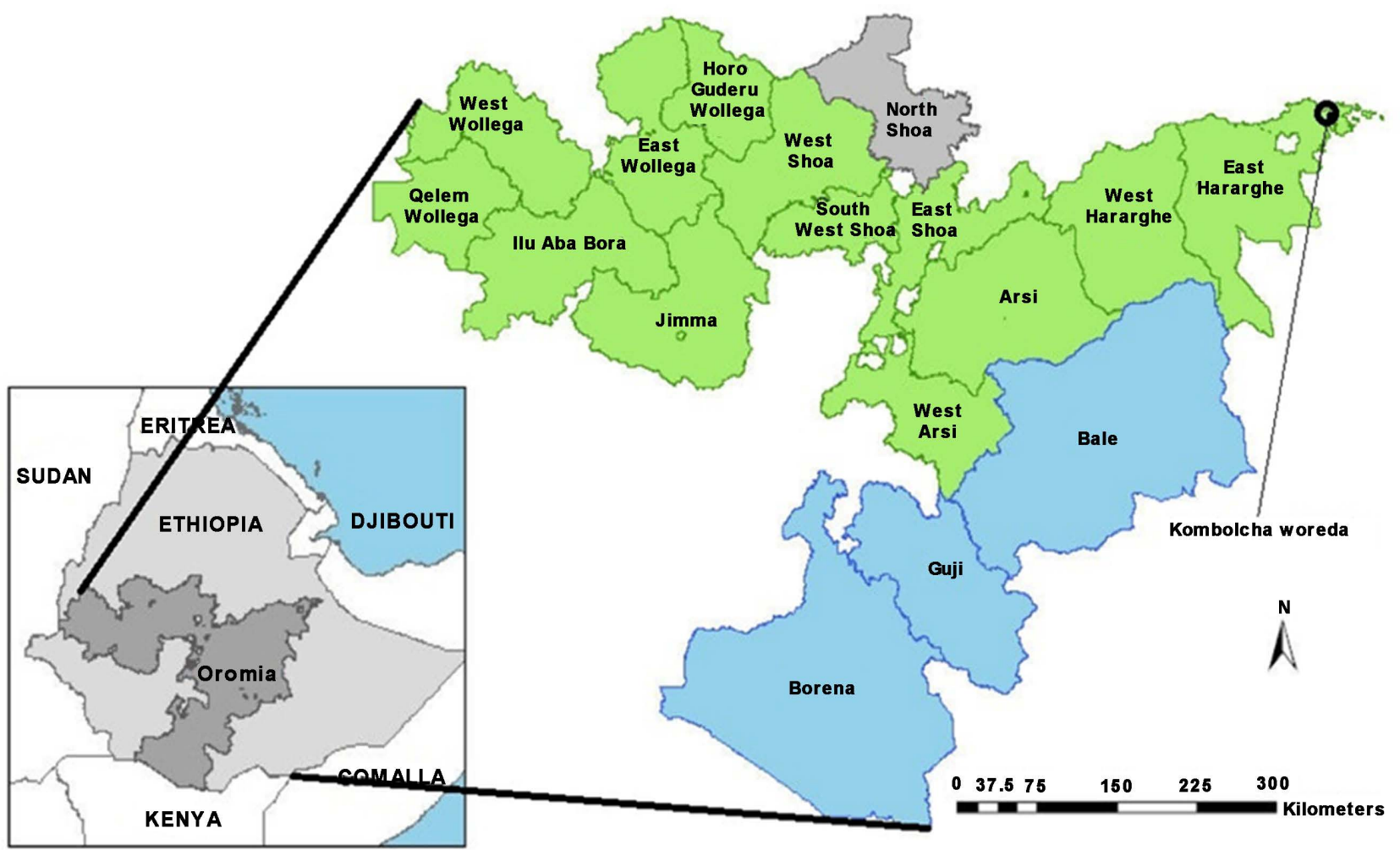

Figure 1. The study area.

\subsection{Population}

The 2007 national census reported a total population of 140,080 of whom 70,967 were men and 69,113 were women; 12,615 or $9.01 \%$ of its population were urban dwellers. The majority of the inhabitants are Muslim, with $98.29 \%$ and the remaining are follower of Ethiopian Orthodox Christianity. The two largest ethnic groups reported in Kombolcha were the Oromo (92.55\%) and the Amhara $(7.2 \%)$

\subsection{Selection of the Study Sites; Home Gardens and Informants}

A Reconnaissance survey of the study area was conducted on October 2016 to see whether the area is suitable to meet the objectives stated during that period, overall information on the study area was obtained and representative sampling site were identified by consulting the elders and the residents of the town. The town was divided in to three representative sampling sites (Ganda hasho, Weloye sefer and Ganda kesi) for data collection was based on the presence of traditional home garden practices. House holders in shaping and rented houses were purposively excluded since they do not have space to cultivate home garden plants.

Therefore only households who have their own compounds and have access to and control over gardens plants were considered for study. After the domain of the households to be considered for the study is demarcated as stated above sampling frame was made based on the study aims and available budget.

According to (Cotton, 1996), the site of the sample depends on available fund, 
time and other reasons and not necessarily the total population. Hence a total of a 180 households (60 for each site) were randomly selected to determine the frequency of home gardens and to identify those types (front-yard, back-yard, side-yard, and others) the list of all households that fell in the domain were received from the town residences and workers after which the total number of those households divided by a sample size to determine sampling intervals for each sample site during the random selection. For data collection and analysis 60 home gardens (twenty home gardens from each site) were preferentially selected from houses as pointed out by 11 . When recording indigenous knowledge held by certain social groups the choice of key informants for the study was done through available sampling. Accordingly a total of 16 persons which are believed to be knowledgeable persons between the ages of $(20$ - 70) were selected from different sites (Rosenthal, 1997).

\section{Data Collection}

\subsection{Ethno Botanical Data Collection}

Ethnobotanical data was collected during January to April 2017 using methods such as filed observation, semi structured interview, market survey, and questionnaires' survey following the procedure recommended by (Martin, 1995) cited in (Feleke, 2000) and (Cotton, 1996), the interviews and FGDs were conducted in Amharic and Oromifa languages since these were the languages well understood by all informants and the vegetation and ethno-botanical data's were collected in line with the principles stated in (Vogl et al., 2004) and (Whittaker, 1993).

\subsection{Home Gardens Observation}

Home gardens observations were made using observation checklist having columns of recording homegarden direction, plant diversity, and other important parameters and by laying quadrants in each homegarden. Semi structured interview was made with systematically selected key informants and with home garden owners in each site during ethno botanical data collection.

\subsection{Semi Structured Interview}

Questions were used during data collection included local name of the gardens species and purpose of the home gardens grown plants management's practices. The importance of these home gardens for in-situ conservation of plants diversity and others data related to environmental change indicators. The key informants were selected based on the number of years they live in the area and the states of their homegarden and dependency. They were encouraged to discuss the cultural (ritual uses, social use and medicinal use of the homegarden) and ecological knowledge (discussed the use of homegardens for conservation of soil water plant biodiversity and shade for other plants like coffee), to identify the plants with their use including the functions of the plants and parts used. 


\subsection{Market Survey}

A market survey was conducted to record the variety and amounts of food and other home garden plant products produced and supplied to the local market. Plants that have market values in Kombolcha market were identified through observation on the market survey, and interview by interacting with producers, seller, and buyer by using the starter question.

\subsection{Data Analysis}

Following Ethnobotanical data collection, descriptive statistical methods such as densities, frequencies, relative densities, Shannon and wiener index for species diversity and Sorensen's index of similarities were used to analyze the data collected in the sites. Vegetation data collection carried out according to Whittaker 1993 principle.

\subsection{Frequency}

Frequency describe as the distribution of a species through stand frequency class were calculated to estimate the heterogeneity and homogeneity of species by following (Martin, 1995).

$$
\text { Frequency }=\frac{\text { frequency of species in the home garden } A}{\text { total number of sample in home gardens }} * 10
$$

\subsection{Relative Frequency}

It is the distribution of one species in a sample relative to the distribution of all, this calculate with the formula (Martin, 1995).

Relative frequency $=\frac{\text { frequency of species in the home gardens } A}{\text { Total frequency of all species in the sample of home gardens }}$

\subsection{Density}

Density is the average number of individuals of a species on a unit area basis. It is closely related to abundance of but more useful in establishing the importance of a species (Martin, 1995).

$$
\text { Density }=\frac{\text { dnumber of individual in the sampley }}{\text { Total area of the sample }(m 2)}
$$

\subsection{Relative Density}

Relative density is the number of individual of species as a percentage of the total number of individual of all species in the area (Martin, 1995).

Relative density $=\frac{\text { number of individual of a specis in the sample }}{\text { total number of indevidual of all speices in the sample }} * 10$

\subsection{Similarity among Home Gardens}

Sorensen index of similarity was also used to compare the degree to which spe- 
cies composition of samples in the study area Sorensen index.

$$
S_{S}=2 a / 2 a+b+c
$$

where; $\mathrm{S}_{\mathrm{s}}=$ Sorensen similarity coefficient;

$a=$ number of species common to sample;

$b=$ number of species in sample 1 ;

$c=$ number of species in sample 2 .

The coefficient values range from 0 (complete dissimilarity) to 1 (total similarity) (Kent and Coker 1992).

\subsection{Shannon Wiener Diversity Index}

The Shannon-wiener index is the most commonly used diversity indicator in plant communities, and it takes a value of zero when there is only one species in a community, and a maximum value, when all species are present in equal abundance (Shannon and Weaver 1949).

$$
H=\sum_{i=1}^{S}-(p i * \ln p i)
$$

where; $H=$ the Shannon index;

$P i$ fraction of the entire population made of species $i$;

$S=$ number of species encountered;

$\Sigma=$ sum from species 1 to species and "In" is the natural logarithm to the base e $(\log )$.

\subsection{Simpson's Diversity Indices}

The term "Simpson's diversity index" can actually refer to any one of three closely related indices. The Simpson Index compares the number of a species to the total population of a given area. Simpson's index $(D)$ measures the probability that two individuals randomly selected from a sample which belong to the same species (or some category other than species). There are two versions of the formula for calculating $D$. either is acceptable, but be consistent.

The simplest formula is $D=\sum(n / N)^{2} O R$

$$
D=\frac{\sum n(n-1)}{N(N-1)}
$$

where; $N=$ Refers to total number of all species;

$N=$ Refers to the total number of a particular species.

\subsection{Simpson's Index of Diversity: 1-D}

The value of this index also ranges between 0 and 1, but now the greater the value, the greater the sample diversity. This makes more sense. In this case, the index represents the probability that two individuals randomly selected from a sample that belong to different species.

\subsection{Relative Abundance Richness}

This method simply counts up the number of each individual observed or col- 
lected and divides by the total number observed or collected.

$$
R A=n / N
$$

\subsection{Species Richness}

This method was simply count the number of different species which were observed, regardless of abundance.

\section{Result and Discussion}

\subsection{Structure of Home Garden in Kombolcha Town}

According to the observation made out of 180 household 128 practiced home gardening in case of spatial arrangement of the homegardens 60 gardens were found in the back yard of their houses where as 18 were side gardens in some cases the gardens found on both front and side or side and back sides Table 1. Distinct variations in site diversity and composition were encountered increasingly with increasingly in holding site. As the site of home gardens increase, as diversity of plant species increases. Home gardens on the study area are composed of trees, shrubs, herbs, and climbing plants in different strata. They consist of trees approximately $10-15 \mathrm{~m}$ on the upper strata, fruit crops $1 \mathrm{~m}$ to $10 \mathrm{~m}$ middle strata and herbaceous plants up to $1 \mathrm{~m}$ from the ground strata.

\subsection{Local Knowledge and Management of Home Gardens Is Kombolcha Town}

Local peoples have developed a general home garden structure with considerable diversity and flexibility that facilitates production of the major livelihood necessities. They have managed to select crops that are co-adapted and that give multiple benefits. Home garden are found surrounding the home of the owner where he/she gets daily requirement of fruit, vegetables, fodder, medicinal plants and some plants with cultural values.

According to the information during semi structured interview of homegarden owners of home gardens in the study area most of them grow vegetables during the rainy season of the year and also in the time of water scarcity by

Table 1. Samples of the selected kebele homegarden.

\begin{tabular}{|c|c|c|c|c|c|c|c|c|}
\hline Kebeles (places) & $\begin{array}{l}\text { No houses } \\
\text { surveyed }\end{array}$ & $\begin{array}{c}\text { Houses with } \\
\text { home gardens }\end{array}$ & $\begin{array}{c}\text { Front yard } \\
\text { gardens }\end{array}$ & $\begin{array}{l}\text { Back yard } \\
\text { gardens }\end{array}$ & $\begin{array}{l}\text { Side yard } \\
\text { gardens }\end{array}$ & $\begin{array}{l}\text { Front and side } \\
\text { yard gardens }\end{array}$ & $\begin{array}{l}\text { Back and side } \\
\text { yard gardens }\end{array}$ & $\begin{array}{l}\text { Round yard } \\
\text { gardens }\end{array}$ \\
\hline 1 & 60 & 40 & 5 & 16 & - & 1 & 12 & - \\
\hline 2 & 60 & 38 & - & 24 & 10 & - & 5 & 8 \\
\hline 3 & 60 & 50 & 9 & 20 & 8 & 2 & 4 & 4 \\
\hline Total & 180 & 128 & 14 & 60 & 18 & 3 & 21 & 12 \\
\hline Percent \% & & 71.1 & 7.78 & 33.33 & 10 & 1.67 & 11.67 & 6.67 \\
\hline
\end{tabular}

Source: researchers observation 2017. 
fetching water and watering home garden cultivated plants at least twice a week, as it was mentioned by some of the owners of home gardens continuous production of plants for the house hold benefits, maintains the ecological system and makes the gardens sustainable. Planting shrubs near the homegarden in erosion prone areas were management's practices done by owners of home gardens in the study area. Home gardens were near house hold or further away $2-4 \mathrm{mi}-$ nutes walking distance with living houses in some study sites to get more cultivable land for home gardening and cope up with shortage of land. Home gardens could be observed with open areas, fenced or semi-fenced. Live fences with trees and shrubs to protect home garden species from predators (domestic animals) were more frequently observed activity as management's practices. Home gardens allow all family members to be involved in some form or another. It allows for greater participation by female members. According to (Shannon and Weaver 1949), link between the local communities and plant resource is essential for conservation and as a part of biodiversity conservation.

\subsection{Diversity of Species in Homegardens of Kombolcha Town}

Homegardens are typically populated by a wide Varity of plants, varying from small herbs total trees. From this study 78 species which are under 35 families were recorded from 18 homegardens surveyed (Table 2). The representative families and number of species under each family were found families like Solonaceae, and Rutaceae ranks top of the list 6 species each followed by Fabaceae and Lamiaceae consistes of 5 specieseach and Asteraceae, Poaceae, Rosaceae and Brassicaceae represented by 4 species each.

All plant species found in home gardens were used in the calculation of diversity index and evenness (Table 3) plant species with highest diversity were also identified in this study among them, Catha edulis, lantana camara and Ruta chalepensis had a highest frequency in that order diversity index with the value $\left(\mathrm{H}^{\prime}\right.$ $=3.08)$ highest for site- 3 and followed by site- $1\left(\mathrm{H}^{\prime}=2.9665\right)$ and the lowest diversity index $\left(\mathrm{H}^{\prime}=2.904\right)$ for site- 2 as confirmed by owners of home gardens diversity of plant species are affected by different factors like, lack of access water, size of home gardens, pests and weeds on the study area. Sorensen similarity index among the sampling sites is (0.296) or lower than 0.5 which should that slight similarity. These communities do not have much over lap or similarity on kombolcha town home gardens.

Table 2. Total number of species with their respective family.

\begin{tabular}{ccccc}
\hline Sites & Richness & Shannon & Evenness & Sorensen index (Ss) \\
\hline Ganda hasho & 25 & 2.9665 & 0.922 & 0.296 \\
Weloye sefer & 26 & 2.904 & 0.891 & \\
Ganda kesi & 25 & 3.08 & 0.957 & \\
\hline
\end{tabular}

Source: researchers observation 2017. 
Table 3. Species richness in the homegardens.

\begin{tabular}{|c|c|c|c|c|c|}
\hline No. & Family name & Number of species & No. & Family name & Number of species \\
\hline 1 & Amaryllidaceae & 3 & 19 & Musaceae & 1 \\
\hline 2 & Apiaceae & 3 & 20 & Myrtaceae & 3 \\
\hline 3 & Asteraceae & 4 & 21 & Oleaceae & 1 \\
\hline 4 & Anacaridiaceae & 1 & 22 & Poaceae & 4 \\
\hline 5 & Acanthaceae & 1 & 23 & Pedaliaceae & 1 \\
\hline 6 & Arecaceae & 1 & 24 & Polygonaceae & 2 \\
\hline 7 & Brassicaceae & 4 & 25 & Phytolaccaceae & 1 \\
\hline 8 & Boraginaceae & 1 & 26 & Rubiaceae & 1 \\
\hline 9 & Chenopodiaceae & 2 & 27 & Ranunculaceae & 1 \\
\hline 10 & Caricaceae & 1 & 28 & Rutaceae & 6 \\
\hline 11 & Celastraceae & 1 & 29 & Rhamanceae & 1 \\
\hline 12 & Cupressaceae & 3 & 30 & Rosaceae & 4 \\
\hline 13 & Cactaceae & 1 & 31 & Solonaceae & 6 \\
\hline 14 & Convolvulaceae & 1 & 32 & Verbenaceae & 3 \\
\hline 15 & Euphorbiaceae & 2 & 33 & Xantnorrhoeaceae & 1 \\
\hline 16 & Fabaceae & 5 & 34 & Zingiberaceae & 1 \\
\hline 17 & Flacourtiaceae & 1 & 35 & Lamiaceae & 5 \\
\hline 18 & Lauraceae & 1 & & & \\
\hline
\end{tabular}

Source: researchers observation 2017.

\subsection{Functional Category of Home Gardens in Kombolcha Town}

The homegardens on the study area have been suggested in to different functional uses categories. The categories suggested during the key informants interview were categorized as nutritional supply, stimulant, spices, medicinal plants and multipurpose trees.

\subsection{Nutritional Supply from Home Gardens}

Food producing plants are cultivated in the study however significant amounts of nutrient supplying homegarden products are more available during the main rainy season between June and September. As informants described during interview majority of these food and nutritional plants were fruits and vegetable that are cultivated through the year and directly used for house hold food and nutrition sources. Homegarden owners' responses reflected that adding fruits and vegetables to their daily meal helped them to stay healthy in addition to this the plantation of fruit and vegetables will also help them in their social interaction with their neighbors (Table 4).

\subsection{Stimulant Plants from Homegardens}

The second identified functional category of home gardens plant species were stimulants. The key informants in the study area identified three plant species as 
Table 4. List of nutrition supply plant species on the study area.

\begin{tabular}{|c|c|c|c|c|}
\hline No. & Scientific name & Local name & Plant habit & Use of plant \\
\hline 1 & Carica papaya $L$. & Papaya (Am) & Herb & Fruit \\
\hline 2 & Casimiroa edulis La Llave & Abuker (Am) & Tree & Fruit \\
\hline 3 & Citrus aurantifolia (christm) swingle & Lomi (Am or Or) & Tree & Fruit \\
\hline 4 & Citrus sinensis $(L$,$) osb.$ & Birtukan (Am) & Tree & Fruit \\
\hline 5 & Capsicum annuum $L$. & Kariya (Am) & Herb & Vegetable \\
\hline 6 & Malus sylvestris Mill. & Apple (Am) & Shrub & Fruit \\
\hline 7 & Manigifera indica $L$. & Mango (Am) & Tree & Fruit \\
\hline 8 & Persia Americana Mill. & Abocado (Am) & Tree & Fruit \\
\hline 9 & Saccharum officinarum $L$. & Shenkorageda (Am) & Shrub & Sugar source crop \\
\hline 10 & Zea mays $L$. & Bekolo (Am or OR) & Herb & Cereal \\
\hline 11 & Vicia faba $L$. & Bakila (Am, OR) & Herb & Pulse \\
\hline 12 & Ocimum basilicum $L$. & Besobila (Am) & Herb & Spice \\
\hline 13 & Daucus carota $L$. & Carrot (Am) & Herb & Vegetable \\
\hline 14 & Solonum tuberosum $L$. & Dinich (Am) & Herb & Tuber crop \\
\hline
\end{tabular}

stimulant plants. The key informants suggested that these category plants as a major income generating groups in the area. From the three suggested plant species chat is dominant in the area as a source of income (Table 5).

\subsection{Spices Plants from Homegardens}

The other functional category identified in the homegardens plant species was spice. In this category a total of 10 species recorded with their application. As indicated in Table 6 the spices are either used for household purpose and some spices are used as income generating means.

\subsection{Medicinal Plants from Home Gardens}

The study revealed that homegardens in Kombolcha town are serving as ecologically and culturally important systems for cultivating medicinal plants for wellbeing of human and its domesticated animals by healers and urban dwellers. The medicinal plants species, parts used, preparation and application methods were recorded (Table 7). Dwellers and traditional healers believe that growing medicinal plants in home gardens is having a doctor at home. The ease of the use and the affordability makes it popular to be planted in every garden. The power to heal almost every human health disorder, animal disorder and crop pest problems also another importance raised during the key informants interview.

\subsection{Multipurpose Tree Species}

According to the key informants discussion and the response from the questionnaire among the functional groups multipurpose tree species are one of the 
Table 5. Lists of stimulant plants growing in Kombolcha town homegardens.

\begin{tabular}{ccccc}
\hline No. & Scientific name & Local name & Part used & Application \\
\hline $\mathbf{1}$ & Catha edulis & Chat & Young leaves & Chewing young leaves \\
$\mathbf{2}$ & Nicotiana tabacum & Timbaho (Am) & Leaves and shoots & Used for smoking and chewing \\
$\mathbf{3}$ & Coffea arabica & Buna (Am) & Seed and leaf & Used as hot beverage \\
\hline
\end{tabular}

Table 6. Lists of spice plants growing in Kombolcha town homegardens.

\begin{tabular}{|c|c|c|c|c|}
\hline No. & Scientific name & Local name & $\begin{array}{c}\text { Parts used and } \\
\text { preparation method }\end{array}$ & How to use \\
\hline 1 & $\begin{array}{l}\text { Allium ceppa } L . \text { var } \\
\text { aggregatum. Don }\end{array}$ & $\begin{array}{c}\text { Yeabesha key } \\
\text { shinkurt }\end{array}$ & $\begin{array}{c}\text { Bulbs chopped in to } \\
\text { pieces }\end{array}$ & Added to wot making \\
\hline 2 & Allium sativum $L$. & Nech shinkurt & $\begin{array}{l}\text { Bulbs chopped in to } \\
\text { pieces/grouned }\end{array}$ & Added to wot making \\
\hline 3 & Brassica nigra (L.) Koch & Senafinch & $\begin{array}{l}\text { Young leaves and seeds } \\
\text { gring together }\end{array}$ & $\begin{array}{c}\text { Commonly used in raw } \\
\text { meat }\end{array}$ \\
\hline 4 & Rosmarinus officinalis $L$. & Sigametbesha & Leaves & Added to roasting meat \\
\hline 5 & $\begin{array}{l}\text { Lippie adoensis Hochst.ex } \\
\text { walp. Var. koseret sebsebe }\end{array}$ & Koseret & $\begin{array}{l}\text { Dried leaves together } \\
\text { with flower bunches }\end{array}$ & $\begin{array}{l}\text { Used for butter } \\
\text { processing }\end{array}$ \\
\hline 6 & Capsicum frutescens $L$. & Mitimita & $\begin{array}{l}\text { Dry pods along with } \\
\text { seeds floured together }\end{array}$ & $\begin{array}{l}\text { Added to wet making, } \\
\text { added to different meals }\end{array}$ \\
\hline 7 & Capsicum annuum $L$. & $\begin{array}{c}\text { Kariya or } \\
\text { berbere }\end{array}$ & $\begin{array}{l}\text { Dry pods along with } \\
\text { seeds floured together }\end{array}$ & $\begin{array}{l}\text { Commonly used } \\
\text { on raw meat }\end{array}$ \\
\hline 8 & Ocimum basilicum $L$. & Besobila & $\begin{array}{l}\text { Leaves together with } \\
\text { flower bunches }\end{array}$ & $\begin{array}{l}\text { Added to wot either in } \\
\text { fresh or powder form }\end{array}$ \\
\hline 9 & Ruta chalepensis L. & Ten adam & Top young branches & $\begin{array}{l}\text { Added to coffee and } \\
\text { berbere processing }\end{array}$ \\
\hline 10 & $\begin{array}{c}\text { Rhammus prinoides } \\
\text { L'Herit }\end{array}$ & Gesho & Top part & Local beer preparation \\
\hline
\end{tabular}

groups. Plant species with various uses such as construction, furniture and equipment, fire wood, charcoal, shade tree and others were grouped under multipurpose functions. In this group the most dominant family was mirtaceae comprising of 2 species (Table 8). The most dominant tree found in the homegarden were Eucalyptus camaldulensis and Eucalyptus globules due to the wide range of use it gives to the society. According to the key informants other tree species were not planted rather the plants grew by themselves without the intervention of human but the two dominant species become dominant due to high degree of plantation takes place in the area for their wide range of use.

\subsection{Marketed Home Gardens Species on Kombolcha Town}

According to market survey that done on kombolcha town during the study almost all study sites the road access enables farmers to produce cash crops. The most marketed home gardens species listed below are ranked based on the observation on the market, and from the information collected through key informant's interview and the rank collected from the questionnaire (Table 9). Chat 
Table 7. Lists of medicinal plants.

\begin{tabular}{|c|c|c|c|c|c|c|}
\hline No. & Scientific name & Local name & $\begin{array}{l}\text { Alignments } \\
\text { claimed to be cured }\end{array}$ & Parts used & Preparation & Application \\
\hline 1 & Allium sativum $L$. & Nech shinkurt (Am) & $\begin{array}{l}\text { Stomach, cancer, } \\
\text { cholesterol, } \\
\text { wound etc... }\end{array}$ & Bulb & Raw or half cooked & Oral \\
\hline 2 & Artimisa absinthium & Arity (Am) & $\begin{array}{c}\text { Throat ache stomach } \\
\text { ache }\end{array}$ & Bulb & Chewing & Oral \\
\hline 3 & Beta vulgaris & Keysir(Am) & Constipation & Leaves & Half coking & Oral \\
\hline 4 & $\begin{array}{c}\text { Brassicaoleraceavar } \\
\text { capitata }\end{array}$ & Tikl-gomen (Am) & & Leaves & Half cooked & Oral \\
\hline 5 & Carica papaya $L$. & Papaya (Am) & $\begin{array}{l}\text { Internal parasites } \\
\text { including amoeba }\end{array}$ & Leaves & Crushed dry seeds & Oral \\
\hline 6 & Lantana camara & Yewof kolo (Am) & $\begin{array}{c}\text { Insecticides } \\
\text { (against aphids) }\end{array}$ & $\begin{array}{l}\text { Seeds and fresh } \\
\text { leaves }\end{array}$ & $\begin{array}{l}\text { Spraying water over } \\
\text { and stocking for } 7 \\
\text { days }\end{array}$ & $\begin{array}{l}\text { Spraying the liquid } \\
\text { from stocked } \\
\text { materials over } \\
\text { infested plants }\end{array}$ \\
\hline 7 & Lipedium sativum & Feto (Am) & $\begin{array}{l}\text { Stomach and skin } \\
\text { wounds }\end{array}$ & Fresh leaves & Gridding & Oral \\
\hline 8 & Nicotinia tabacum & Timbaho (Am) & $\begin{array}{l}\text { Cattle cough/excretory } \\
\text { system infection }\end{array}$ & $\begin{array}{l}\text { Fresh or dried } \\
\text { leaves }\end{array}$ & Crushing & Oral \\
\hline 9 & Otostegia integrifolia & Tungit & $\begin{array}{c}\text { Human abdominal } \\
\text { diseases, chicken insect }\end{array}$ & $\begin{array}{l}\text { Leaves with young } \\
\text { branch }\end{array}$ & Fumigation & Smoking \\
\hline 10 & Ruta chalepensis & Tenadam (Am) & Stomach ach, measles & Leaf & Chewing & Oral \\
\hline
\end{tabular}

Table 8. Lists of multipurpose tree species.

\begin{tabular}{|c|c|c|c|c|c|c|}
\hline \multirow{2}{*}{ No. } & \multirow{2}{*}{ Species } & \multirow{2}{*}{ Local name } & \multicolumn{4}{|c|}{ Functions } \\
\hline & & & Fire wood & Construction & Charcoal & Shades \\
\hline 1 & Eucalyptus camaldulensis & Key bahirzaf & $\checkmark$ & $\checkmark$ & $X$ & $\checkmark$ \\
\hline 2 & Eucalyptus globules & Nech bahirzaf & $\checkmark$ & $\checkmark$ & $X$ & $\checkmark$ \\
\hline 3 & Junipers procera & Gatira (orm) & $X$ & $\checkmark$ & $X$ & $\checkmark$ \\
\hline 4 & Acacia abyssinica & $\operatorname{Girar}(\operatorname{amh})$ & $X$ & $X$ & $\checkmark$ & $X$ \\
\hline 5 & Olea europaea & Ejersa (orm) & $X$ & $X$ & $\checkmark$ & $\checkmark$ \\
\hline 6 & Caroton macrostachy & Bekenisa (orm) & $X$ & $X$ & $\checkmark$ & $\checkmark$ \\
\hline 7 & Cordial Africana & Wanza $(a m h)$ & $\checkmark$ & $\checkmark$ & $X$ & $X$ \\
\hline
\end{tabular}

Table 9. Show that marketed home gardens species.

\begin{tabular}{cccc}
\hline No. & Species & Local name & Its rank on the market survey \\
\hline 1 & Catha edulis & Chat & 1 \\
2 & Lycopersicum esculentum & Timatim & 2 \\
3 & Allium ceppa L. & Yeabesha key shinkurt & 4 \\
4 & Brassica oleraceae L. var. capitata. & Tikll gomen & 5 \\
5 & Solanum tuberosum & Dinich & 3 \\
\hline
\end{tabular}


was considered as number one marketed species in the town were as other vegetables are taken the rank from two up to five. Even if market survey and economic valuation of homegarden products aren't the outcome of this research it is clearly observable that the cash crop in the area is highly dominated by chat. This species will benefit the farmer's a lot better income than the rest of the homegarden products. A kilo of chat coasts from 1500 - 2500 Eth birr with equivalent currency of $65-100$ USD. The variety of chat determines the price of the chat.

\subsection{The Role of Home Gardens for Plant Biodiversity Conservation in Kombolcha Town}

Home gardens contain many types of species and the genetic diversity which serves not only as a source of food, fuel wood, medicinal plant, construction materials and income in many countries around the world but also they are very important for in-situ conservation of plant genetic resources. There are different plants with different life forms for different uses planted in homegardens of the study area. These trees are conserved by local communities for their use as different functional category.

The study site as a site for in situ conservation consists of number of plant diversity, such as wild, cultivated and indigenous for subsistence use and income generating of the household. Among these plant species, Catha edulis and Coffea arabica are the frequently maintained cash crop. According to Eprem G et al. 2016 the diversity of plants in eastern hararge is high the coffee varieties are decaffeinated that they need conservation. (Zemede \& Ayele, 1995) commented that the Ethiopian homegardens house many indigenous taxa of crops as clones are found

As the data gathered through questionnaire indicates that from the total of 128 homegarden users 117 agreed that the trees are useful to them that they don't want to remove them from their ground. The rest of the respondents responded that they didn't remove the trees from their homegarden due to the fact that they believe that they will not do any harm in their farm yard. Key informants interview reviles that they don't clear the trees and shrubs from their filed for their use. As key informants response most of the medicinal plants in the forest were extinct from their natural habitat due to illegal forest clearing so it is becoming difficult to find medicine that they save those trees and shrubs in their farm yard as shed or fence plants. The major problem raised as a challenge for conservation was youth attitude towards medicinal, aromatic and useful plants is low Figure 2.

\section{Discussion}

The key informant's interview revealed that the plants in the homegarden belonging to 35 families which supports the assertion that homegardens are valuable sources of plant agrobiodiversity. It was found that food plants (fruits, vegetables, spices and other catagories) constituted $25 \%$, of the recorded 


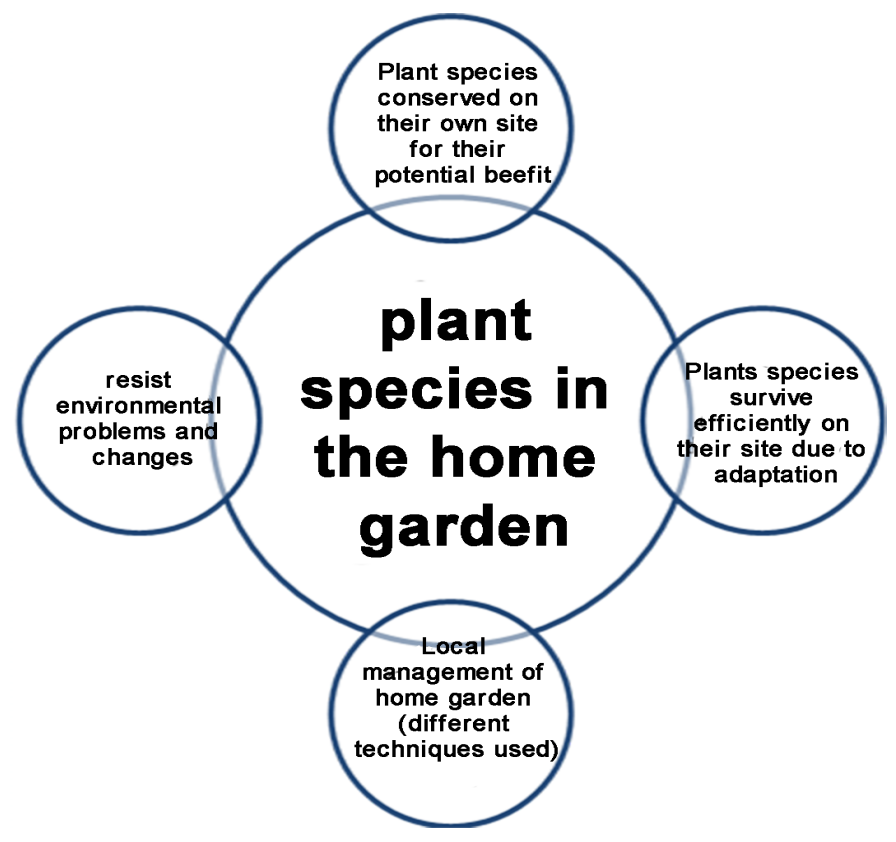

Figure 2. Home gardens for in-situ conservation of plant diversity.

homegarden species which is in agreement with findings of studies conducted in Sabata town of Ethiopia (Habtamu \& Zemede, 2011) and (Belachew et al., 2003) in Diniio Gade homegarden South easte of Ethiopia where the most frequently maintained crops in the homegardens of Kombolcha town were reported to be those that serve as source of food.

Even if the uses of homegardens is not comparable and complementary with crop fields in many areas of Ethiopia, homegardens have been considered primitive and less productive and less attention has been given (Zemede et al., 2011). The homegardens in Kombolcha district facing less attraction as compared to the main farm yard due to the same reason mentioned above. This has resulted in loss of the traditional home garden management systems, loss of taxa and indigenous knowledge. Similar result and implication has been reflected by (Hilenbrand, 2006) according to the research bacterial wilt disease has also played its own part in destroying very useful ENSET varieties it was due to loss of indigenous knowledge.

The role of home gardens in generating income to families in Ethiopia has also been reported by different authors (Tigist W. et al., 2006, Adugna \& Zemede, 2006, Gonzalez, 2011). Focus to grow few cash crops by neglecting other beneficial crops could reduce the diversity of species managed in homegardens. Simple preference ranking exercise conducted on seven marketed homegardens plants in Kombolcha District with the highest frequencies and relative frequencies of occurrence revealed Catha edulis as the most valued marketed homegarden plant, followed by Lycopersicum esculentum and Solonum tuberosum (Table 9). The stimulant plant Catha edulis has been reported as one of five homegarden plants that generate the highest income in Kombolcha town of Ethiopia which 
seems similarly reported by (HAbtamu H. and Zemede A. 2011).

The price variability and the seasonality of coffee (Coffea arabica) and the high demand of chat (Catha edulis) in most of the country has been a great problem for coffee production and it is making the farmers to displacing coffee shrubs by chat. According to (Zemede A. 2002) it is reported that the fast expansion of Xanthosoma sagittifolium become a potential threat to Enset.

For maintenance, the diversity of homegarden species in Kombolcha Town depends on various indigenous management activities. (Belachew et al., 2003, Wondimu et al. 2006) and (Tesfaye et al., 2009) confirmed the same results. Homegarden owners of Welaiyta and Bonga communities sites developed indigenous knowledge about the preparation, classification and cultivating of $E$. ventricosum. With the same manner management practices need to overtake in Kombolcha town to save some of the medicinal and aromatic plant species from extinction. In Wolayta and Gurage zones (Zemede \& Woldu, 1997) reported similar perception with regard to the functions of this plant species. (Zemede A., 2002) remarked that the male family head is often accountable for designing homegarden structure, identifying suitable places for positioning the major crops, monitoring and strongly impacting the structure and direction of homegarden development. The study results confirmed homegardens are useful for the maintenance of good health in developing countries as also reported by UNICEF (1982) and (Burchi et al., 2011).

The traditions of planting nutritional plants and wild plant species in homegardens for medicinal purpose have a vital role to in situ conservation of agrobiodiversity. From a total of plant species identified in the present study, 11\% were used as traditional medicinal plants and distributed among 10 genera in 4 families. The findings obtained were similar to that of (Belachew et al., 2003) that reported 133 plant species grown in the "Gamo" homegardens of which 18 were medicinal plants. Nutraceutical plants are food plants which also have medicinal uses. The term nutraceutical means food or parts of food that offer medical or health benefits. These medicinal plants are alleged to be good remedies for various ailments.

\section{Conclusion}

Home gardens play an important role within the overall farming system. The fact that the majority owners of home garden show that gardening is considered important by farmers influences houses hold food security and income generation. Home gardens provide a diversity of fresh foods that have diverse quality and quantity of nutrients available to a family in a low cost and sustainable manner. It equally contributes to the community health improvement. Home gardens also contribute to the houses hold income through saving from food and medicinal expenses. Home gardens owners and traditional healers have a local knowledge of medicinal plants, parts used, preparation methods and aliment cured.

Home gardens are generally regarded as a very complex species rich 
agro-ecosystem managed in a suitable manner over decades or even centuries. The major purposes of home gardens are subsistence production and income generation, particularly in rural areas. In addition, they fulfill important ecological, social and cultural functions. On the other hand, the majority of the study area community has a good understanding of climate change indicators in their locality and what led those indicators occur. The majority of respondents reflected that over exploitation of natural vegetation of the surrounding leads to failure of rain fall pattern with seasons rising temperature and recurrent drought. Finally, the present study results documented how the study area communities manage to grow and use a wide range of plant species of home gardens diversity. The management system of home gardens with local community and the role of home gardening practice for different functions and for in-situ conservation of plant biodiversity are documented.

Based on the research results, the following recommendation are forwarded: Kombolcha town home gardens owners should be trained on home garden product management and benefit making from sales of surplus products. The participation of the local people and awareness rising through training or education on sustainable management of home garden plant resources should be encouraged. The high diversity of species in home gardens contributes to plant biodiversity conservation. However, the tendency of local people towards the production of few cash is generating, therefore, the local agricultural office should play an active role by educating people to grow diversity plant species. Kombolcha town environmental protection authority and health station should encourage and build on the indigenous knowledge for the local community. Applications of organic farming through use of organic fertilizers and plants (lantana camara) against crop pest management should be promoted by urban agriculture.

\section{References}

Abdi, A., \& Asfaw, Z. (2006). In-Situ (On-Farm) Conservation Dynamics and the Patterns of Uses of Sorghum (Sorghum bicolor (L.) Moench) Landraces in North Shewa and South Welo, Central High Lands of Ethiopia. Ethiop. SINET: Ethiopian Journal of Science 2003, 26, 123-136.

Belachew, W., Asfaw, Z., \& Demissiew, S. (2003). Ethnobotanical Study of Useful Plants in Daniio Gade (Homegardens) In Southern Ethiopia. Ethiop. J. Biol. Sci a, 2, 119-141.

Burchi, F., Fanzo, J., \& Frison, E. (2011). The Role of Food and Nutrition System Approaches in Tackling Hidden Hunger: Review. International Journal of Environmental Research and Public Health, 21, 13-25.

Engels, J. (2002). Home Gardens-A Genetic Resources Perspective. In J. W. Watson, \& P.B., Proceedings of the 2nd International Home Gardens Workshop, 17-19 July 2002, Witzenhausen, Federal Republic of Germany.

Eyzaguirre, P. B., \& Watson, J. W. (2002) Rome: IPGRI Home Gardens and in-Situ Conservation of Plant Genetic Resources in Farming Systems. Proceedings of the 2nd International Home Gardens Workshop, 17-19 July 2001, Witzenhausen, Federal Republic of Germany. 
Eyzaguirre, P., \& Linares, O. (2004). Homegardens and Agro Biodiversity. Washinton, DC: Smithsonian Press.

Galluzzi, G., Eyzaguirre, P., \& Negri, V. (2010). Home Gardens: Neglected Hotspots of Agro-Biodiversity and Cultural Diversity. Biodiversity and Conservation, 19, 3635-3654. https://doi.org/10.1007/s10531-010-9919-5

Gonzalez, C. G. (2011). Climate Change, Food Security, and Agro biodiversity: Toward a Just, Resilient, and Sustainable Food System "Fordham Environmental Law Review (2011)”. Sweden: Uppsala.

Habtamu, H., \& Zemede, A. (2011). Homegardens and Agro Biodiversity Conservation in Sebeta Town Oromia National Regional State, Ethiopia. M.sc Thesis, Addis Ababa University.

Hilenbrand, E. (2006) Improving Traditional-Conventional Medicine Collaboration: Perspectives from Cameroonian Traditional Practitioners. Nordic Journal of African Studies, 15, 1-15.

Kumar, B., \& Nair, P. (2004). The Enigma of Tropical Homegardens. Agroforestry Systems, 61-62, 135-152. https://doi.org/10.1023/B:AGFO.0000028995.13227.ca

Martin, G. J. (1995). Ethnobotany.

Rosenthal, J. P. (1997). Plants, People and Culture: The Science of Ethnobotany by M. J. Balick (New York Botanical Garden) and P. A. Cox (Brigham Young University). Scientific American Library, New York, NY. 1996. ix + 228 pp. $22 \times 24$ cm. $\$ 32.95$. ISBN 0-7167-5061-9. Journal of Natural Products, 60, 428-429.

Tesfaye, H., Sebsibe, D., \& Zemede, A. (2009). An Ethnobotanical Study of Medicinal Plants Used Bylocal People in the Lowlands of Konta Special Wereda, Sothern Nations, Nationalities and People Regional State, Ethiopia. Journal of Ethnobiology and Ethnomedicin, 5, 1-15.

Vogl, C. R., Vogl-Lukasser, B., \& Puri, R. K. (2004). Tools and Methods for Data Collection in Ethnobotanical Studies of Homegardens. Field Methods, 16, 285-306. https://doi.org/10.1177/1525822X04266844

Whittaker, R. J. (1993). Holocene Book Reviews: Vegetation Description and Analysis: A Practical Approach M. Kent and P. Coker, London: Belhaven Press, 1992,363 pp., $£ 45.00$, hardback. ISBN 1-85293-006-3. The Holocene, 3, 379-379.

Woldyes, F. (2000). A Study on Biodiversity Management in Daddegoyo (Traditional Homegardens) by Kafficho People of Bonga Area (South western Ethiopia): An Ethnobotanical Approach. PhD Thesis Unpublished Addis Ababa University.

Wondimu, T., Asfaw, Z., \& Kelbessa, E. (2006). Ethnobotanical Study of Food Plants around "Dheeraa" Town, Arsi, Ethiopia. SINET: Ethiopian Journal of Science, 29.

Zemede, A., \& Ayele, N. (1995). Home-Gardens in Ethiopia: Characteristics and Plant Diversity. SINET, an Ethiopian Journal of Science, 18, 235-266.

Zemede, A., \& Woldu, Z. (1997). Crop Associations of Home Gardens in Welayta and Gurage in Southern Ethiopia. SINET: Ethiopian Journal of Science, 20, 21-32.

Zemede, A., Sebsebe, D., Bernard, R., \& Feleke, W. (2011). Home Gardens and Spices of Basketo and Kafa (Southwest Ethiopia): Plant Diversity, Product Valorization and Implications to Biodiversity Conservation. PhD Thesis Unpublished A.A.U. 